\title{
Transiciones: la imagen y su significado en unas representaciones mixtecas de Cristo del siglo XVI
}

\section{Transitions: Image and Meaning in Sixteenth-Century Representations of Christ}

Artículo recibido el I8 de octubre de 20I7; devuelto para revisión el I5 de mayo de 20I8; aceptado el 20 de junio de 20I8, https://doi.org/I0.2220I/iie.18703062e.20I8.I13.2656

Alessia Frassani Universidad de Leiden-Facultad de Arqueología, alessiaf@ymail.com

Publicaciones más relevantes Building Yanhuitlan: Arts Politics, and Religion in the Mixteca Alta, since I500 (Oklahoma: University of Oklahoma Press, 2017), y Artistas, mecenas y feligreses en Yanhuitlán, Mixteca Alta. Siglos XVI-XXI (Ciudad de México/Bogotá: Universidad Nacional Autónoma de México-Instituto de Investigaciones Estéticas/Ediciones Uniandes, 2017).

Resumen El ensayo discute la peculiar representación estilística e iconográfica de la imagen de Cristo en una pintura y un relieve de la segunda mitad del siglo xvI, pertenecientes al patrimonio artístico y religioso de Santo Domingo Yanhuitlán, un pueblo de la Mixteca oaxaqueńa, México. El análisis estilístico e iconográfico junto a unos relevantes datos históricos apuntan a la existencia de una clara reflexión en torno a la naturaleza y estatus de la imagen sagrada en el debate religioso postreformista y el contexto de fruición local.

Palabras claves piedad, descendimiento, Yanhuitlán, pasión, Contrarreforma.

Abstract The essay discusses the peculiar stylistic and iconographic represen-
tation of Christ in two images (one sculpted and one painted) from
the church of Santo Domingo Yanhuitlán, in the Mixtec highlands
of Oaxaca, Mexico. Historical data complement the formal analy-
sis of the artworks and point to the engagement with current issues
on the role of sacred images in the post-Reformation period and the
local political situation.

Keywords descent from the cross, Yanhuitlán, passion, Counter-Reformation. 
DOI: http://dx.doi.org/10.22201/iie.18703062e.2018.113.2656 
DOI: http://dx.doi.org/10.22201/iie.18703062e.2018.113.2656

\author{
ALESSIA FRASSANI \\ FACULTAD DE ARQUEOLOGÍA \\ UNIVERSIDAD DE LEIDEN
}

\title{
Transiciones: \\ la imagen y su significado en unas representaciones mixtecas de Cristo del siglo XVI
}

$\mathrm{E}$ 1 convento dominico en Yanhuitlán, Oaxaca, es una de las obras más ambiciosas llevadas a cabo en la Nueva España en la segunda mitad del siglo Xvi. Cronistas coloniales y estudiosos modernos han discutido ampliamente la importancia del conjunto en la historia del arte colonial del país. ${ }^{I}$ Detrás de esta imponente construcción, empezada en 1550 , se esconden décadas de pugnas y negociaciones que empezaron con el establecimiento de la encomienda en $\mathrm{I} 523$, otorgada al conquistador extremeño Francisco de las Casas, primo de Hernán Cortés. ${ }^{2}$ Mientras las relaciones políticas con oficiales españoles llegaron rápidamente a un acuerdo pacífico, la misión evangelizadora desató una firme oposición por parte del yya (cacique) y demás gobernadores del pueblo. El gobernante hereditario mixteco, don Domingo de Guzmán, estableció una firme alianza con el conquistador español con el propósito, entre otros, de evitar la presencia dominica en el pueblo. La Corona llegó a quitar la encomienda a Francisco de las Casas, preocupada por el estrecho vínculo político entre los dos hombres y estableció un corregimiento durante un breve

I. Como por ejemplo, fray Bernabé Cobo en el siglo xvir y Manuel Toussaint en la década de I920, en Wigberto Jiménez Moreno y Salvador Mateos Higuera, Códice de Yanhuitlán (México: Museo Nacional, 1940), 49-51.

2. Esta compleja historia ha sido estudiada y analizada en Jiménez Moreno y Mateos Higuera, Códice de Yanhuitlán, así como en Alfonso Pérez Ortiz, Tierra de brumas: conflictos en la Mixteca Alta, I523-1550 (México: Plaza y Valdés, 2003). 
periodo (I526-I529). Quince años después (I544-I546), la intervención de la Santa Inquisición amenazó directamente el liderazgo mixteco en Yanhuitlán y su alianza con el encomendero. El proceso inquisitorial dejó largos testimonios que evidencian el papel preponderante jugado por el encomendero Francisco de las Casas en contra de la presencia dominica. ${ }^{3}$ Las motivaciones que llevaron a varios pueblos cercanos a delatar al cacique y a los gobernadores de Yanhuitlán acerca de supuestas actividades prohibidas tenían más bien que ver con el pago de tributo y la importancia que el pueblo y cacicazgo de Yanhuitlán habían adquirido después de la Conquista gracias a la relación privilegiada con el encomendero. Como lo ha estudiado Ethelia Ruiz Medrano, fueron numerosos, aún sin éxito, los intentos por parte de autoridades indígenas, conquistadores y frailes españoles por ganar autonomía o hasta independencia política de la Corona mediante alianzas estratégicas. ${ }^{4}$ Estos mismos intentos fueron reprimidos utilizando la Santa Inquisición como instrumento de persecución política.

A los pocos ańos de concluirse los procesos inquisitoriales, una nueva generación llegó al poder en Yanhuitlán. El hijo del encomendero Francisco de las Casas, Gonzalo, siguió la estrategia paterna y forjó una alianza con el cacique Gabriel, sobrino de Domingo. Al mismo tiempo, la presencia de los religiosos ya no pudo detenerse y la construcción del asentamiento dominico empezó en 1550 para concluirse hacia finales de $1579 .{ }^{5}$ ¿Qué tensiones provocó la convivencia forzada entre las partes? ¿Qué visión tenían de su pueblo y qué significado tenía la participación social de los mixtecos en las instituciones religiosas impuestas por el régimen colonial? Con estas preguntas en mente, en las páginas que siguen se analizan dos obras fechables en los años que nos ocupan, a saber, la segunda mitad del siglo xvi y más probablemente, el último cuarto.

3. Richard Greenleaf, The Mexican Inquisition of the Sixteenth Century (Albuquerque: University of New Mexico Press, 1969), 75-8I.

4. Ethelia Ruiz Medrano, "Fighting Destiny: the Nahua Nobles and the Friars in the $16^{\text {th }}$-Century Revolt of the Encomenderos against the King”, en eds. Susan Kellogg y Ethelia Ruiz Medrano, Negotiation within Domination. New Spain's Indian Pueblos confront the Spanish State (Boulder: University Press of Colorado, 2010), 45-77; Ethelia Ruiz Medrano, "Don Carlos of Tezcoco and the Universal Rights of Emperor Carlos V", en eds. Jongsoo Lee y Galen Brokaw, Texcoco: Prehispanic and Colonial Perspective (Boulder: University Press of Colorado), 264 y 284.

5. Para una reconstrucción documental, véase Alessia Frassani, "El centro monumental de Yanhuitlán y su arquitectura: un proceso histórico y ritual”, Desacatos, núm. 42 (2013): I47-I48. 
I. Descendimiento, sacristía de la iglesia de Yanhuitlán, México.

Foto: Alessia Frassani.

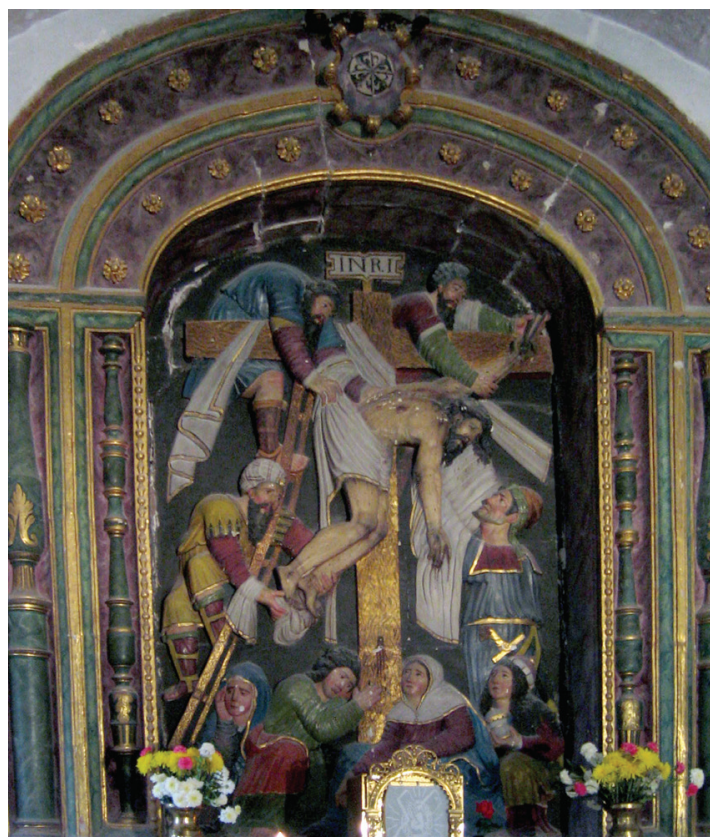

Las obras en cuestión son un bajorrelieve del Descendimiento (fig. I) que se encuentra en la capilla del Sagrario adjunta a la iglesia y que según Francisco de Burgoa servía para honrar la memoria de los frailes que habían trabajado y fallecido en el convento; ${ }^{6}$ y una pintura al óleo sobre tabla que representa una Piedad (fig. 2), hoy custodiada en las bodegas de la iglesia, pero que parece haber pertenecido a la iglesia y no al convento, pues se utilizó desde principios del siglo xx para reemplazar tablas o lienzos robados en algunos altares laterales de la iglesia. ${ }^{7}$ Ambas piezas representan distintos temas, pero comparten la misma atención hacia el cuerpo de Cristo muerto, sostenido, movido y manipulado por José de Arimatea y Nicodemo, en presencia de la Virgen, san Juan y otras mujeres. Los diversos estilos, las fuentes y las soluciones formales adoptadas en las dos obras nos hablan de la riqueza y vitalidad del ambiente artístico y religioso de Yanhuitlán en la segunda mitad del siglo Xvi.

6. Francisco de Burgoa, Geográfica descripción (Ciudad de México: Talleres Gráficos de la Nación, 1934), 295.

7. Manuel Toussaint, Paseos coloniales (Ciudad de México: Imprenta Universitaria, 1939), 23. 


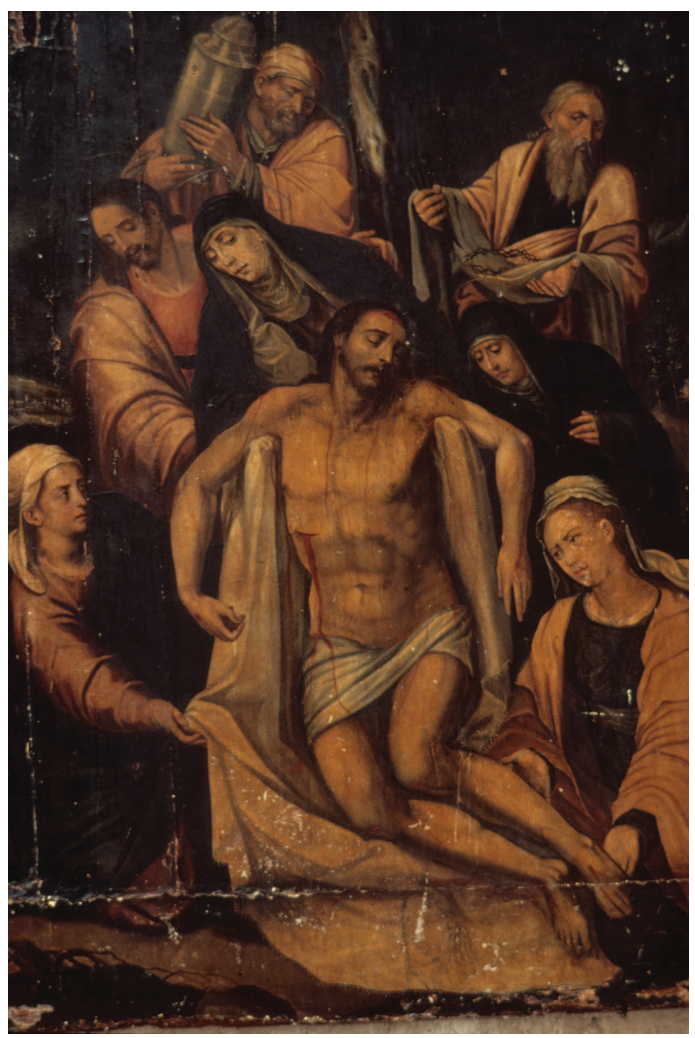

2. Piedad, iglesia de Yanhuitlán.

(C) Getty Conservation Institute.

El conjunto conventual, así como el altar principal han sido objeto anteriormente de un estudio detallado. ${ }^{8}$ La imponente arquitectura manifiesta la finalidad política de esta gran obra para el establecimiento de un nuevo orden colonial en el valle. Los dos trabajos objeto del presente texto, por otro lado, pertenecen a un contexto religioso de ámbito más bien restringido y permiten entonces un acercamiento diferente al arte religioso en este pueblo mixteco, más enfocado en la imagen religiosa y el complejo debate y las teorías artísticas que se generaron alrededor de ella en el siglo Xvi.

En el bajorrelieve del Descendimiento (fig. I) se empleó una técnica eminentemente ibérica perteneciente a la tradición retablística que fusiona formas

8. Alessia Frassani, "The Convento of Yanhuitlan and its Altarpiece: Patronage and the Making of a Colonial Iconography in I6th-Century Mixteca Alta", Colonial Latin American Review 22, núm. I (2013): 67-97. 
arquitectónicas, escultóricas y pictórico-narrativas. Las columnas balaustres del marco del nicho son características del estilo llamado plateresco o "a la romana”, una variante española del primer Renacimiento clásico. ${ }^{9}$ La composición de la escena y las figuras que aparecen en ella tienen el estilo de la escultura castellana y vallisoletana, en particular, contemporánea, representado por maestros y talleres como Esteban Jordán (véase el trascoro de la catedral de León), ${ }^{10}$ Manuel Álvarez y Francisco Giralte (retablo del Doctor Corral en Valladolid). Las proporciones y anatomía de derivación clásica, cuyos modelos habían entrado a España a través del manierismo italianizante de Alonso Berruguete, se descartan en favor de cuerpos más redondeados, cuya anatomía se esconde debajo de pańos gruesos y abundantes, y proporciones corpulentas. Este aspecto en particular permite ver algunas semejanzas entre el Descendimiento del sagrario y las esculturas más o menos contemporáneas del altar mayor (fig. 3), hecho que apunta a una autoría común de las obras, fruto del mismo artista o al menos del mismo taller. El altar mayor de la iglesia de Yanhuitlán, punto culminante de los trabajos de construcción de la iglesia, fue obra de Andrés de Concha, uno de los más importantes artistas de la Nueva España en la segunda mitad del siglo XVI. ${ }^{\text {II }}$

Por otro lado, la Piedad, que puede considerarse más o menos contemporánea, muestra otro estilo más marcadamente manierista y de ascendencia flamenca. Así lo evidencian los rostros muy delgados, las proporciones alargadas de los cuerpos y la insistencia en dibujar los pliegues de los paños. En la Nueva España, el exponente más importante de esta corriente fue sin duda Simón de Pereyns, cuya carrera artística en la Nueva España se entrelazó ínti-

9. Diego de Sagredo, Medidas del romano (Toledo: Juan de Ayala impresor, I549), I6v-I8v.

Io. George Kubler, Mexican Architecture of the Sixteenth Century (New Haven: Yale University Press, 1948), 408.

II. Al respecto, González Leyva propone que ni las pinturas ni las esculturas del retablo del altar mayor de la iglesia son fechables para el siglo XVI, quedando así descartada la autoría del maestro sevillano Andrés de Concha. La autora opina que son del siglo XviII, cuando se rehizo el retablo después de un gran temblor que sacudió la región en i7ir. A mi manera de ver, esta postura carece de fundamento y creo que no hay razón en dudar que las tablas y las tallas son del siglo XVI, obra de Concha y su taller. El retablo es del siglo XVIII, como consta en la documentación de archivo (Archivo Histórico del Juzgado de Teposcolula [en adelante AHJT], Sección Civil, leg. 26, exp. 6). Véase Alejandra González Leyva, "Las pinturas y esculturas del retablo mayor", en El convento de Yanhuitlán y sus capillas de visita: construcción y arte en el país de las nubes, ed. Alejandra González Leyva (México: Universidad Nacional Autónoma de MéxicoFacultad de Filosofía y Letras/Consejo Nacional de Ciencia y Tecnología, 2009), 285-317. 


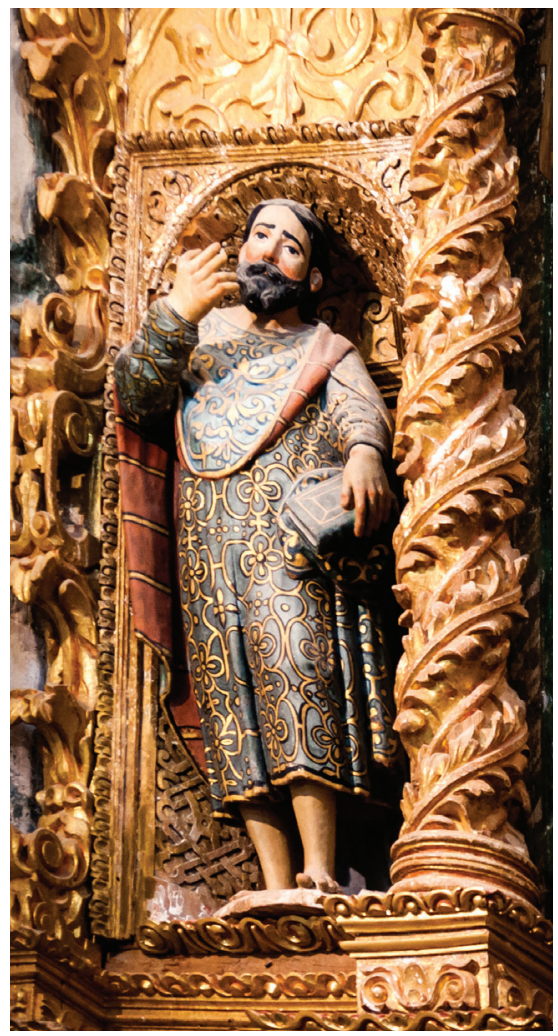

3. Escultura del altar mayor, iglesia de Yanhuitlán. Foto: Javier García.

mamente con la de Concha. Sevillano uno, amberino el otro, los dos colaboraron frecuentemente, adaptándose a clientelas tan diversas como los frailes dominicos en la Ciudad de México, las cofradías en la Catedral Metropolitana de la misma ciudad, y los cabildos indígenas en los pueblos de Huejotzingo, en Puebla, y Teposcolula, Tamazulapan y Achiutla en la Mixteca oaxaqueña. ${ }^{12}$ El legado artístico de los dos maestros en la Nueva España no fue solamente

I2. Véase Carmen Sotos Serrano, "De artistas y mecenas: Andrés de la Concha y sus relaciones con la sociedad novohispana", Memorias de la Academia Mexicana de la Historia, núm. 49 (2007-2008: 187-239); José Guadalupe Victoria, "Un pintor flamenco en Nueva Espańa, Simón Pereyns", Anales del Instituto de Investigaciones Estéticas XIV, núm. 55 (1986): 69-83. La importancia del mecenazgo indígena para las carreras artísticas de Pereyns y Concha ha sido analizado en Frassani, "The Convento of Yanhuitlan", 70-74. 
material, puesto que entrenaron a futuras generaciones de pintores y retablistas. ${ }^{\mathrm{I3}} \mathrm{El}$ variado ámbito sociocultural en el cual trabajaron los dos artistas y la marcada diferencia estilística que los caracteriza son indicativos de un mecenazgo de gusto sofisticado y patrocinio ambicioso. Entender estas imágenes requiere de esfuerzos metodológicos específicos.

El Descendimiento y la Piedad, por su carácter estrictamente religioso-devocional y no público o cívico, ofrecen la oportunidad de aproximarse específicamente a la manera como se manejaba la ortodoxia religiosa católica en un ambiente cultural indígena y misionero, pero en el cual ideas y costumbres cristianas y españolas circulaban desde hace dos generaciones. En las páginas a seguir, se argumenta que las características iconográficas y estilísticas apuntan a un mecenazgo local sofisticado y bien enterado del significado de la imagen sacra en el mundo español y mesoamericano. Así, se incorporan estudios recientes sobre el debate alrededor de la imagen sacra en Europa, pero a la luz de datos puntuales relativos al uso de las imágenes y los espacios religiosos en el pueblo de Yanhuitlán, documentado desde la época colonial temprana.

\section{El Descendimiento}

El bajorrelieve del Descendimiento que se encuentra en el Sagrario, área que servía como sepulcro de los religiosos, tenía de acuerdo con esta función todas las paredes y la bóveda pintadas "al temple de colores mortificados". ${ }^{\mathrm{I} 4}$ Como menciona explícitamente Burgoa, el relieve había sido mandado a encarnar por parte del prior del convento sólo a mediados del siglo Xvir. Esta noticia es muy importante, porque nos muestra que el relieve original era de color blanco o gris, posiblemente con algunas partes en oro u otro color, mientras que hoy la imagen presenta colores brillantes. Para hacernos una idea de cómo pudo haber lucido el bajorrelieve de Yanhuitlán podemos ver algunas obras de artistas de la escuela vallisoletana que trabajaron la técnica del relieve en mármol o alabas-

I3. María de los Ángeles Romero Frizzi, Más ha de tener este retablo (Oaxaca: Instituto Nacional de Antropología e Historia-Centro Regional de Oaxaca, 1978), 6-8; Teresa Mora y María Sara Molinari Soriano, Tradición e identidad: Semana Santa en Yanhuitlán, Oaxaca (Ciudad de México: Plaza y Valdés/Consejo Nacional para la Cultura y las Artes/Instituto Nacional de Antropología e Historia, 2002), 94. Véase también la documentación en el Archivo Histórico del Juzgado de Teposcolula, Sección Criminal, leg. 3, exp. I5.

14. Burgoa, Geográfica descripción, 295. 


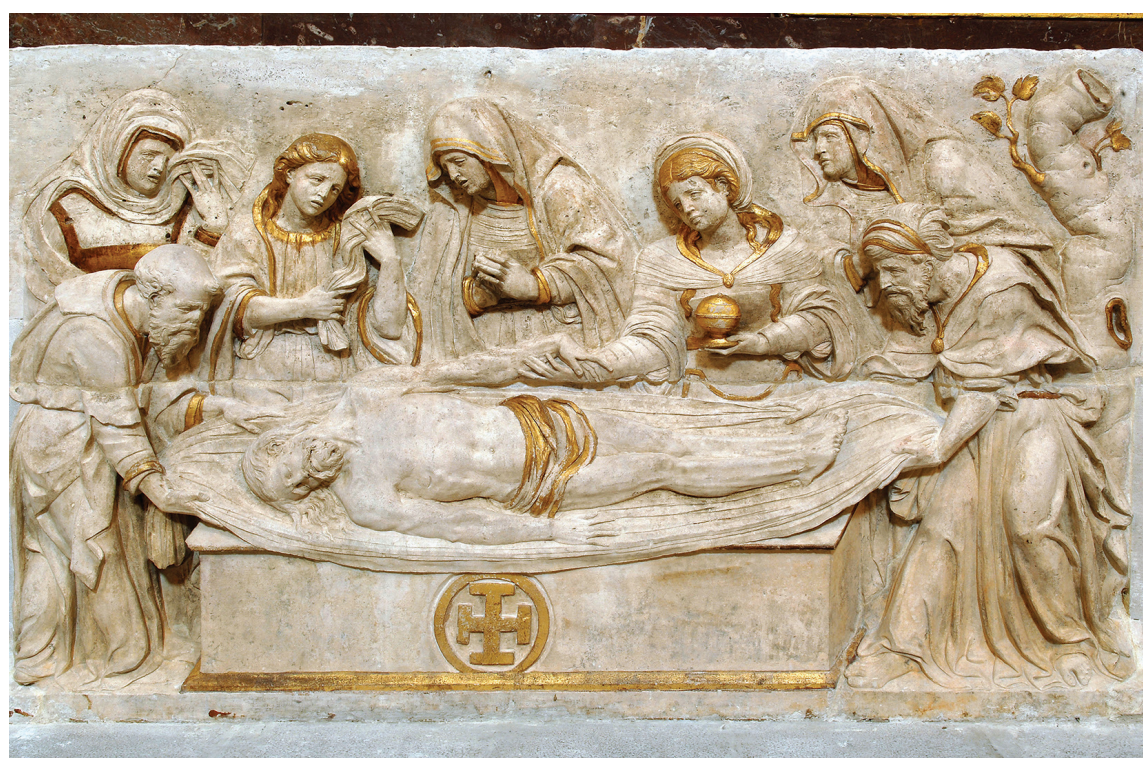

4. Anónimo, taller burgalés, Entierro de Cristo, primer tercio del siglo XVI, $\mathrm{II} 2 \times 192 \mathrm{~cm}$. (C) Museo Nacional de Escultura, Valladolid, Espańa.

tro en escenas pasionarias (fig. 4). A pesar de que no se tiene notica acertada del material de soporte, según el mismo Burgoa, éste está hecho en mármol, información igualmente reportada por Toussaint. ${ }^{15}$ Guillermo Tovar de Teresa opinó que se trata de alabastro, mientras que recientemente Alejandra González Leyva aseveró que se trata de piedra arenisca caliza, misma que se encuentra en los muros de la sacristía, cubierta de argamasa. ${ }^{16}$

En la Nueva España, las representaciones carentes de color (grisalla) fueron muy comunes en la pintura mural de los conventos en el siglo XVI, sin que su frecuencia haya llamado la atención de los estudiosos modernos. En una breve reflexión, Samuel Y. Edgerton sugiere que los "colores mortificados", en palabras de Burgoa, tienen relación con las actitudes católicas de continencia y autocontrol moral en boga en la época de la Contrarreforma. A este propósito,

15. Toussaint, Paseos coloniales, 2 I.

I6. Guillermo Tovar de Teresa, Pintura y escultura en Nueva España (I557-I640) (Ciudad de México: Grupo Azabache, I992), I85; González Leyva, El convento de Yanhuitlán y sus capillas de visita, 152. 


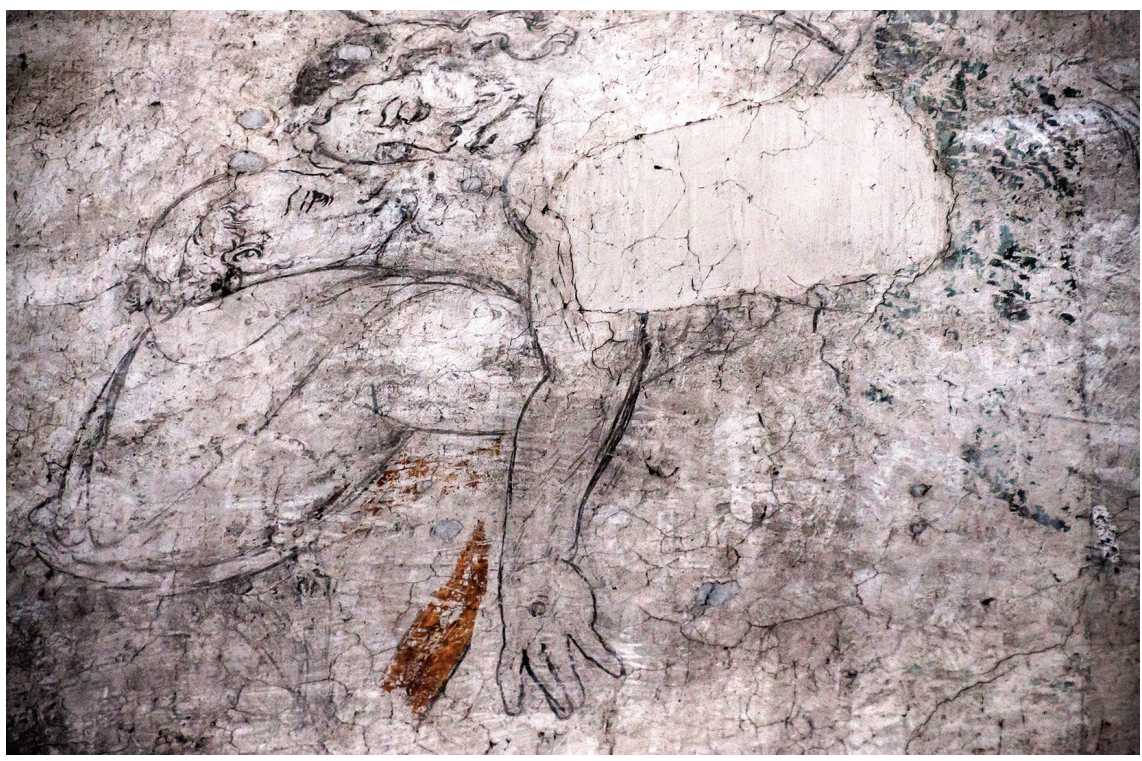

5. Descendimiento, detalle, iglesia de San Miguel Huejotzingo, Puebla. Foto: Javier García.

el autor cita las técnicas leonardescas del esfumado y claroscuro, empleadas por generaciones enteras de artistas del Renacimiento para escrutar la relación ambigua y difícil del hombre con su entorno natural. ${ }^{17} \mathrm{~A}$ mi modo de ver, sin embargo, en las pinturas murales en grisalla de la Nueva Espańa cualquier elemento atmosférico, aspecto fundamental de la técnica de Leonardo, está ausente. No hay tinieblas disueltas por la luz, sino estudios anatómicos y de perspectiva, que subrayan las características físicas y tridimensionales de los objetos, cuerpos y espacios, con un claro contraste entre el fondo y los personajes en primer plano.

Éste es el caso de los ciclos pasionarios en los murales de Huejotzingo, Puebla (fig. 5), y Teitipac (fig. 6), en los valles centrales de Oaxaca, cuyas representaciones dan pistas para entender la relevancia de los colores mortificados en el Descendimiento de Yanhuitlán. En Huejotzingo, la pintura mural se encuentra en la nave principal de la iglesia, mientras que en Teitipac el ciclo pictórico se desarrolla en la portería del convento. En ambos casos, la escena que me ocupa es parte de una narrativa más larga que incluye la Crucifixión (como

17. Samuel Y. Edgerton, Theaters of Conversion: Religious Architecture and Indian Artisans in Colonial Mexico (Albuquerque: University of New Mexico Press, 200I), I27. 
un momento anterior al Descendimiento) y la procesión del Santo Entierro (posterior) a lo largo de un espacio rectangular que envuelve al espectador. Igualmente, en Huejotzingo y Teitipac, la escena de la deposición de Cristo se encuentra encima de una puerta, de manera que destaca de la progresión lineal de la narrativa. Como ha señalado Pablo Escalante Gonzalbo, es probable que con esta estrategia se haya querido subrayar el dramatismo del momento preciso cuando se desclava a Cristo de la cruz y su brazo cae, muerto.$^{18}$ En el caso de Huejotzingo, Elena Estrada de Gerlero y Susan V. Webster (quien también ha estudiado los murales de Teitipac) han traído a colación el relato del cronista dominico Agustín Dávila Padilla para señalar la importancia de las representaciones teatrales que se llevaban a cabo durante la Semana Santa por parte de los frailes y miembros de las hermandades indígenas fundadas en los conventos. ${ }^{19}$ En 1582, Dávila Padilla describió a detalle el procedimiento por el que una imagen de Cristo, hecha en pasta de caña y con los brazos y piernas móviles, se bajaba de la cruz con el uso de un lienzo. Cuando, al quitar el clavo de la mano, caía el brazo, la audiencia no podía evitar el llanto. ${ }^{20}$ Éste es el momento preciso que se representa en Huejotzingo, Teitipac y en el Descendimiento de Yanhuitlán. En todos estos casos, mientras que a Cristo se le representa de una manera prototípica por su barba y cabello largo y el simple paño que cubre su cadera, los que llevan a cabo la maniobra son actores contemporáneos como lo evidencian los trajes que los identifican: frailes y penitentes, en Huejotzingo y Teitipac, españoles con ropa a la morisca en Yanhuitlán.

Pablo Escalante Gonzalbo ha propuesto interpretar el uso de la grisalla en Teitipac como una estrategia para construir una continuidad natural entre la imagen de Cristo, presumiblemente de bulto, y los participantes-actores en carne y hueso, de manera que la escena deja de ser una representación y se vuelve real e inmediata. ${ }^{2 \mathrm{~S}} \mathrm{Sin}$ embargo, hay varios elementos que, a mi parecer,

I8. Pablo Escalante Gonzalbo, "Elogio de la cofradía y arraigo de la fe. La pintura mural de la capilla abierta de San Juan Teitipac (valle de Oaxaca)", en Imágenes de los naturales en el arte de la Nueva España, siglos XVI al XVIII (Ciudad de México: Fomento Cultural Banamex, 2005), 228.

19. Estrada de Gerlero, "El programa pasionario en el convento franciscano de Huejotzingo", Jahrbuch für Geschichte von Staat, Wirtschaft, und Gesellschaft Lateinamerikas, núm. 20 (1983), 643-662; Susan V. Webster, "Art, Ritual, and Confraternities in Sixteenth-Century New Spain: Penitential Imagery at the Monastery of San Miguel, Huejotzingo", Anales del Instituto de Investigaciones Estéticas XIX, núm. 70 (1997): 5-43.

20. Agustín Dávila Padilla, Historia de la fundación y discurso de la provincia de Santiago de México, de la Orden de Predicadores (Ciudad de México: Academia Literaria, 1955), 563 y 564.

2I. Escalante Gonzalbo, "Elogio de la cofradía", 236. 
DOI: http://dx.doi.org/10.22201/iie.18703062e.2018.113.2656

TRANSICIONES：LA IMAGEN Y SU SIGNIFICADO

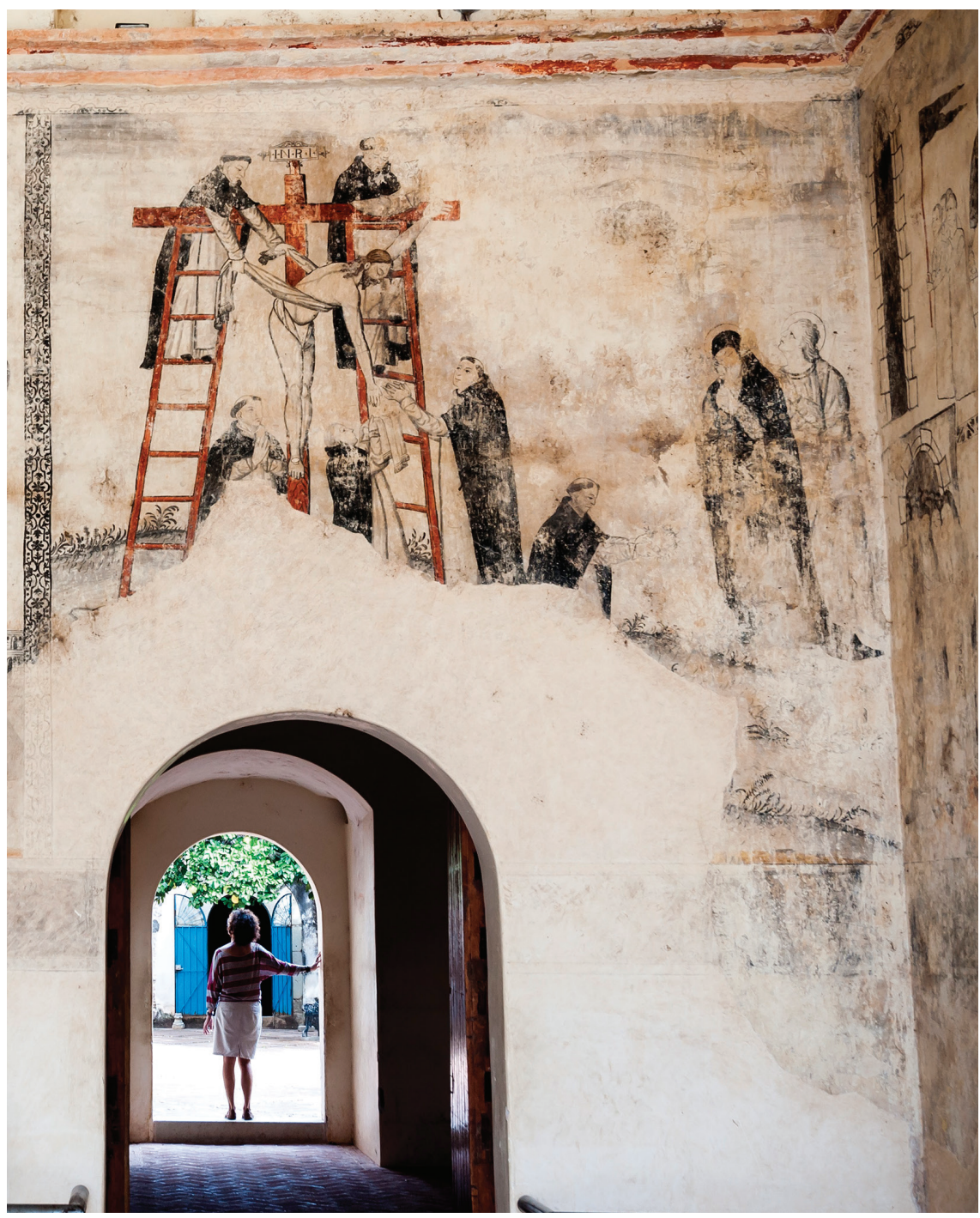

6. Descendimiento, portería del convento de San Juan Teitipac, Oaxaca. Foto: Javier García. 
sugieren una interpretación opuesta. El uso del claroscuro en lugar del color hace que toda la escena se distancie de una inmediatez naturalista para proyectarse en un espacio y tiempo irreal y suspendido. Si bien es cierto que representar personajes reales y esculpidos con las mismas características físicas anula la diferencia entre ambos y los pone en el mismo plano, este plano parece ser más bien ficticio. Los frailes pintados en grisalla se parecen a la imagen de bulto de Cristo y no al revés, debido a la utilización del medio gráfico. Los murales en Teitipac, Huejotzingo y Yanhuitlán son la representación de una representación, esto es, aluden a un acontecimiento que a su vez hace referencia e interpreta otro acontecimiento histórico real. A partir de Aby Warburg, cuyo interés por la grisalla resultó en varias reflexiones teóricas, esta técnica ha sido considerada como una estrategia mediante la cual los mecanismos de construcción de la imagen son revelados como ilusorios respecto al objeto representado. De este modo, se crea así en el espectador la conciencia del engaño y del límite de la representación pictórica. ${ }^{22} \mathrm{El}$ desengaño apunta precisamente a hacer consciente al espectador de que se trata sólo de una imagen y no del objeto real. A pesar de que esta conclusión parece estar en contraste con la interpretación del dramatismo y participación sentida en la escena, subrayados claramente por los cronistas, es necesario tener en mente que estas mismas escenas eran, evidentemente, representaciones teatrales. Como vimos arriba, el momento culminante del Descendimiento visto en las pinturas murales es el instante de la caída del brazo de Jesús una vez quitado el clavo de la mano derecha. Durante el acto, esto provoca efectivamente la caída del brazo de la imagen. Esta última se mueve, entonces parece cobrar vida, pero lo que eso significa, paradójicamente, es que Cristo está muerto, en otras palabras, ya no está aquí. La imagen es a todas luces sólo un muñeco, un reducto o fetiche de una anhelada y efímera presencia divina. La pintura, el bajorrelieve, así como la imagen de bulto y la sacra representación del Descendimiento son solamente imágenes, en el sentido de proyecciones que se refieren a hechos y personajes que no están presentes. ${ }^{23}$ En esta perspectiva, el dramatismo de la escena y la empatía que suscita son apenas la mitad de la historia. La grisalla puede

22. Charlotte Schoell-Glass, "En grisaille: Painting Difference”, en ed. Martin Heusser, Text and Visuality: Word \& Image Interactions 3 (Ámsterdam: Rodopi, 1999), 197-206.

23. Amy Knight Powell, Depositions. Scenes from the Late Medieval Church and the Modern Museum (Nueva York: Zone Books, 20I2), I07-III; Paul Philippot, "Les grisailles et les 'degrés de réalité' de l'image dans la peinture flamande des ise et i6e siècles”, Bulletin des Musées Royaux des Beaux-Arts de Belgique, núm. I5 (1966), 225-242. 
interpretarse como una estrategia para dejar manifiesta la ilusión intrínseca del acto representativo (pictórico, escultórico o teatral), así como finalmente, la incapacidad de colmar la distancia entre lo humano y lo divino. En el altar mayor contemporáneo de Yanhuitlán, el tema del Descendimiento se representa en una tabla que remata el retablo, para indicar que el suceso de alguna manera marca la pauta a la disposición de las tablas inferiores, separándolas en un "antes" y un "después" de la muerte de Jesús. Con el Descendimiento se entiende que la deposición de la imagen cambia definitiva y cualitativamente su estatus.

Otros casos derivados de la experiencia artística e intelectual de las escuelas conventuales del centro de México iluminan el nuestro. Desde la época colonial temprana, la producción de los textos, imágenes, grabados y hasta tipografía involucró directamente a artistas mesoamericanos de varios orígenes, que trabajaban en la recién refundada capital novohispana. ${ }^{24}$ Se crearon libros de carácter religioso (doctrinas, confesionarios, sermonarios) para la conversión de los pueblos indígenas. Al mismo tiempo, intelectuales locales contribuyeron a la redacción de enciclopedias en lenguas nativas (Primeros memoriales, Códice florentino) acerca de su propia cultura. El campo de estudio es vasto, pero vale la pena presentar unos ejemplos específicos. En unas ilustraciones para libros de doctrina (fig. 7) que aparecieron por primera vez en 1553 , artistas novohispanos, y tal vez mesoamericanos, plasmaron el episodio de la vida de Cristo según los cánones de tradición europea. ${ }^{25}$ La técnica gráfica del grabado, basada en el uso del puro trazo y línea, es eminentemente europea, pero se asimiló rápidamente a las formas expresivas autóctonas americanas, como vimos en el caso del monocromo de los murales. ${ }^{26}$ En el contexto de producción libresca, unos años más tarde, alrededor de 1580, la iconografía de la Pasión, muerte y entierro de Cristo se utilizaron de manera original en unas ilustraciones del Libro XII del Códice florentino, al momento de retratar la muerte y entierro de los tlatoani mexica y tlatelolca durante la Conquista (fig. 8). ${ }^{27}$ En las tres viñetas verticales se

24. Marina Garone Gravier, Historia de la tipografía colonial para lenguas indigenas (Ciudad de México: Centro de Investigaciones y Estudios Superiores en Antropología Social/Universidad Veracruzana, 20I4).

25. María Isabel Grañén Porrúa, Los grabados de la obra de Juan Pablos (Ciudad de México: Apoyo al Desarrollo de Archivos y Bibliotecas de México/Fondo de Cultura Económica, 2010), 54-55.

26. El ejemplo tal vez más representativo en este sentido es el claustro bajo del convento de Malinalco, Estado de México.

27. Diana Magaloni Kerpel, "Imágenes de la conquista de México en los códices del siglo XVI. 


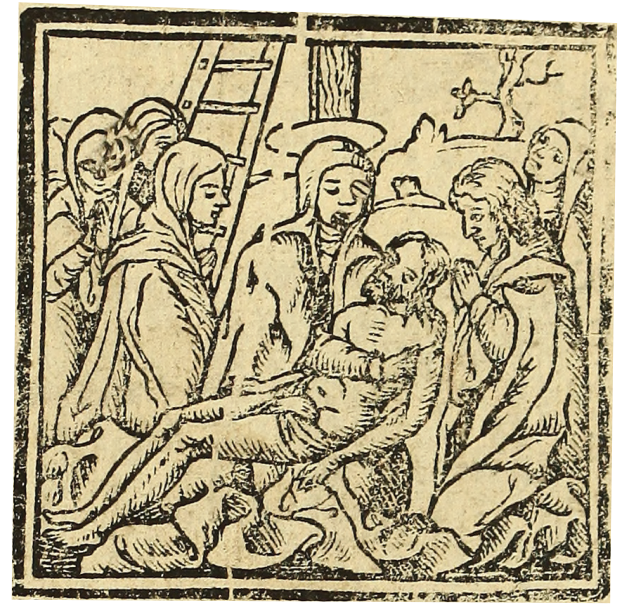

7. Piedad, grabado de la casa de Juan

Pablos, México, ca. $1553,5 \times 5 \mathrm{~cm}$.

The John Carter Brown Library.

muestra cómo los españoles tiraron los cuerpos de Motecuhzoma e Itzquauhtzin a un canal luego recogidos por unos sacerdotes nahuas para ser sepultados. La secuencia narrativa está marcada por una yuxtaposición entre el todo color de la imagen superior, donde el tlatoani mexica es presentado frontalmente como icono, y la parte inferior, en la cual se destaca el carácter mortal del líder fallecido mediante el blanco y negro y el esfumado. Este caso evidencia cómo la apropiación de un modelo representativo (la Pasión de Cristo) pasó mediante la apropiación de una técnica (el grabado), sin que se pueda separar una de la otra. Técnica e imagen juntas hacen referencia implícitamente no sólo a la incorporación del imaginario cristiano al mesoamericano, sino también a los mecanismos de dicha incorporación. Finalmente, los grabados de los libros de doctrina y las ilustraciones de la obra de Sahagún, ambos procedentes de las escuelas conventuales donde se educaba la élite indígena, demuestran que estilos, temas e iconografías europeas formaban parte de la formación artística a lo largo de diferentes regiones novohispanas. Los parecidos no son casuales, si pensamos en la red que los frailes extendieron entre centros metropolitanos y pueblos indígenas desde las primeras décadas después de la Conquista.

Al volver al convento de Yanhuitlán, la relación con la grisalla y el grabado es de suma importancia para entender el Descendimiento del sagrario. La composi-

Una lectura de su contenido simbólico", Anales del Instituto de Investigaciones Estéticas XXV, núm. 82 (2003): 34-42. 
DOI: http://dx.doi.org/10.22201/iie.18703062e.2018.113.2656

TRANSICIONES: LA IMAGEN Y SU SIGNIFICADO

8. La muerte de Motecuhzoma e Itzquauhtzin, Códice florentino, t. III, lib. XII, f. 4 Ov, $20 \times 5 \mathrm{~cm}$. Cortesía de la Biblioteca Medicea Laurenziana, Florencia.

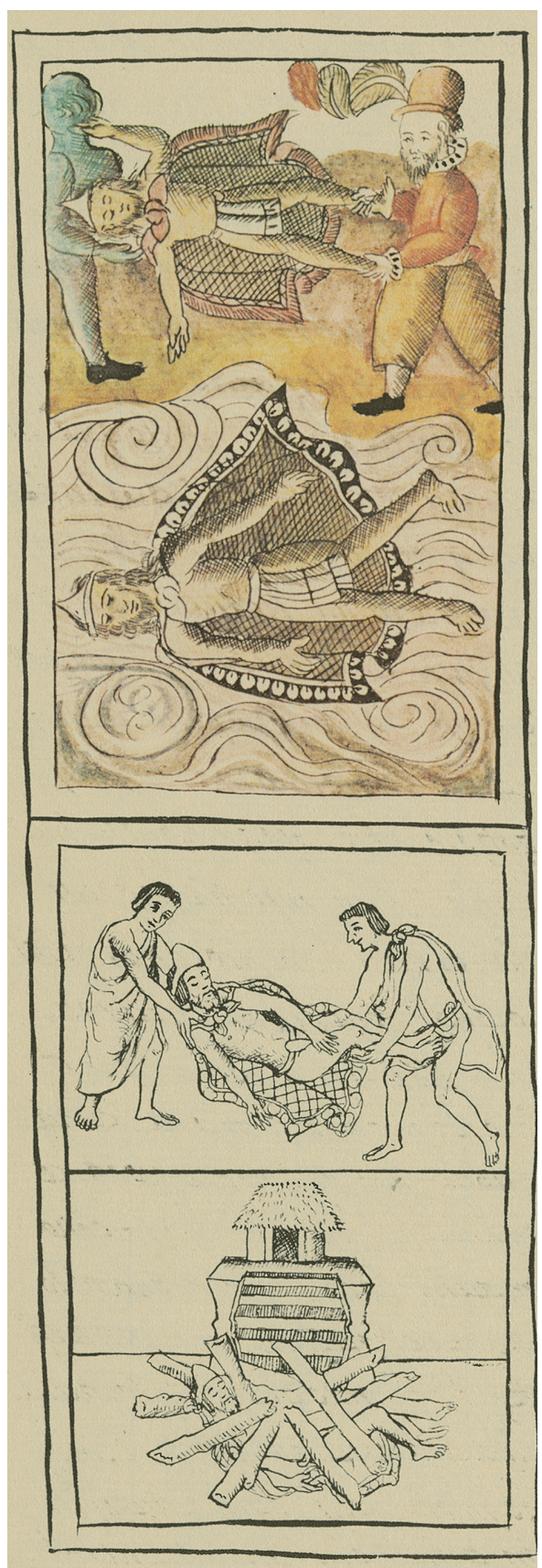




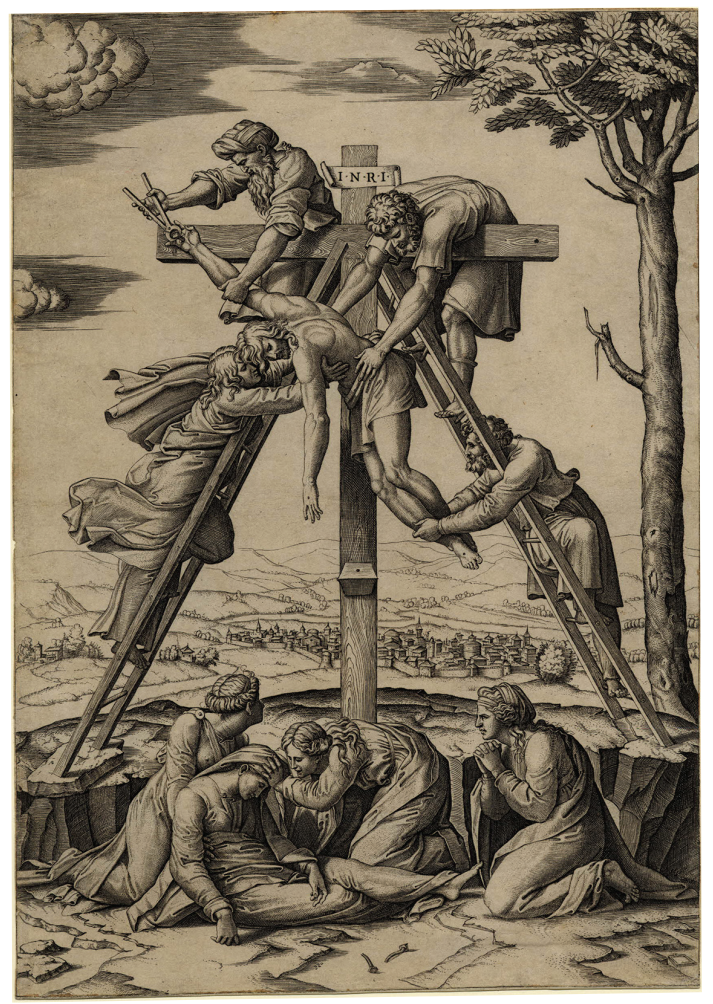

9. Marcantonio Raimondi, Descendimiento, basado en un original de Rafael, $40 \times 28 \mathrm{~cm}$. (C) Trustees of The British Museum, Londres.

ción efectivamente se basa en un conocido grabado de Marcantonio Raimondi, que a su vez parte de un dibujo hoy perdido de Rafael, que circuló ampliamente en Europa (fig. 9). Hay una asociación importante entre el original (el grabado) y la copia, porque esta última parece citar literalmente su fuente, hasta en sus elementos constitutivos propios (el blanco y negro del grabado). Al mismo tiempo, el autor del bajorrelieve, que invirtió la imagen a fin de resaltar que el primer brazo en caer es el derecho, cambió algunos elementos de la escena. Conforme a las características de los bajorrelieves españoles que vimos al principio, cualquier alusión paisajística como telón de fondo se omite. Asimismo, se descarta la sólida composición triangular del original en favor de una mucho más inestable. El hombre de la derecha que se prepara para recibir el cuerpo de Cristo se encuentra a la misma altura que el personaje del lado opuesto, a pesar de que éste está subido en una escalera. El grupo que se encuentra en la parte 
Io. Códice de Yanhuitlán, lám. VIII, $3 \mathrm{I} \times 2 \mathrm{I} \mathrm{cm}, \mathrm{ca}$. 555 . Biblioteca

Lafragua, Puebla. (C) Biblioteca Lafragua, Benemérita Universidad Autónoma de Puebla.

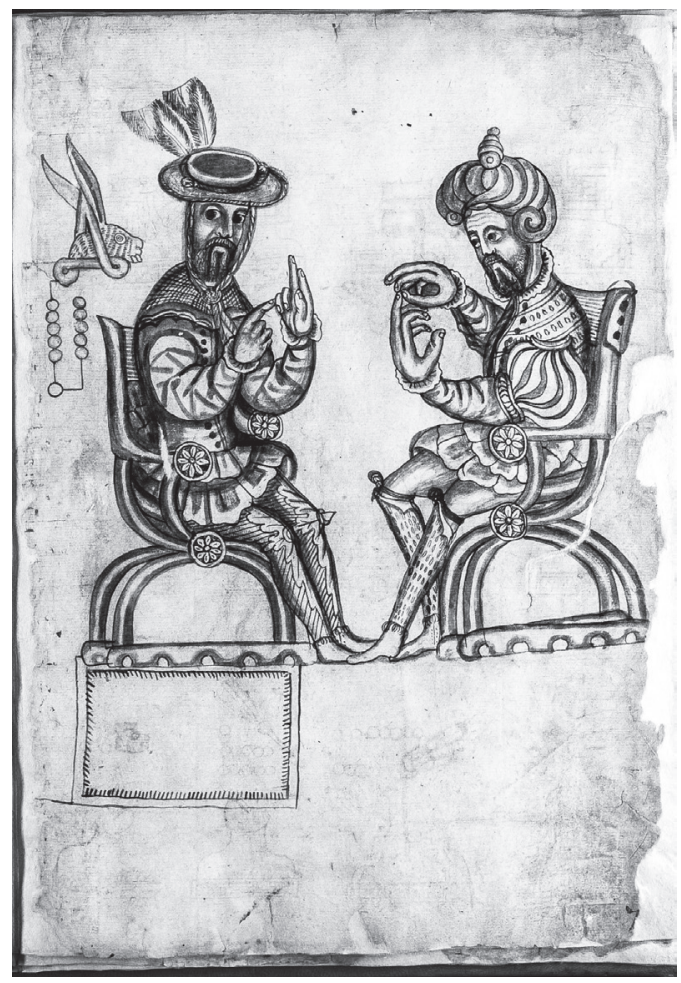

inferior del grabado está constituido por cuatro figuras, san Juan, la Virgen, María Magdalena y otra mujer, cada una absorta en su propio dolor con la mirada vuelta hacia la escena en la parte superior (fig. I). Por último, la clara teatralidad de la escena es subrayada por los ricos vestidos moriscos (turbantes, casacas, entre otros) de los participantes.

Un personaje con turbante también está presente en el grabado de Raimondi y parece aludir a un tipo ideal e históricamente falso de una persona del Oriente cercano. En Yanhuitlán, por otro lado, todos los personajes, con exclusión de la Virgen, san Juan y María Magdalena, exhiben este tipo de atuendo. Así que resulta especialmente interesante notar que en el documento pictográfico conocido como Códice de Yanhuitlán, producido en el pueblo alrededor de I550, aparece un personaje con este tipo de vestimenta (fig. Io), que no era considerada exótica en la España del siglo Xvi, sino que más bien significaba lujo y un 
nivel social alto. ${ }^{28} \mathrm{Si}$ en los casos de Huejotzingo y Teitipac, la representación de los frailes y penitentes (indígenas y españoles) como actores del Descendimiento es una muestra clara de que ellos mismos participaban en el acto, en el caso de Yanhuitlán se puede igualmente argumentar que eran españoles o mixtecos laicos vestidos con ropa de gala los que participaban en la puesta en escena de la Pasión. ${ }^{29}$ El monocromo del Códice de Yanhuitlán ofrece otro interesante ejemplo del uso de la técnica de la grisalla, en este caso por parte de tlacuilos (pintores) mixtecos o nahuas entrenados en las escuelas conventuales. Es hasta probable que el autor del Descendimiento haya conocido el Códice debido a que las dos obras se realizaron en el mismo pueblo y en el mismo periodo.

En el arte europeo contemporáneo la grisalla fue utilizada apenas en pintura mural, más frecuentemente para resaltar detalles escultóricos y arquitectónicos. Entre los ejemplos más relevantes se puede mencionar la escalera del antiguo Hospital de la Caridad de Córdoba (segunda mitad del siglo xvi; hoy Museo de Bellas Artes), por presentar parecidos estilísticos con la pintura mural novohispana, o el Chiostro dello Scalzo, en Florencia, pintado entre I 480 y 1520 en su mayoría por Andrea del Sarto. Ambos casos están relacionados con el mecenazgo laico de hermandades y cofradías. Por otro lado, la pintura en monocromo se asoció con órdenes mendicantes en Toscana desde el siglo Xv, tal como se ve en la famosa obra de Paolo Uccello en el claustro de Santa María Novella en Florencia. A pesar de que estos ejemplos constituyen un antecedente histórico importante para los ciclos murales de los conventos mexicanos, el contexto más estrechamente devocional y cristológico del relieve de Yanhuitlán tiene una relación más clara con el famoso dibujo de la Piedad (ca. 1540) que Miguel Ángel donó a su amiga y confidente Vittoria Colonna (fig. II). La composición de Miguel Ángel es sencilla y monumental, en aparente contraste con su técnica, la del dibujo, normalmente empleada para bocetos. La precisión de la ejecución no deja duda de que el artista quiso acabar su obra. Se trata de un finito, trabajo concluido. Una Roman D’Elia, basándose en el intenso intercambio epistolar entre Miguel Ángel y Vittoria Colonna, ha argumentado que la técnica, iconografía y composición del dibujo apuntan a la creación de una imagen siempre en tensión entre la empatía emotiva y su

28. María Judith Feliciano Chaves, "Mudejarismo in its Colonial Context: Iberian Cultural Display, Viceregal Luxury Consumption, and the Negotiation of Identities in Sixteenth-Century New Spain”, tesis doctoral (Filadelfia: University of Pennsylvania, 2004), I27-I86.

29. Los caciques y demás miembros de la nobleza indígena podían vestir a la española, una vez pedido el correspondiente permiso. 
II. Miguel Ángel, Piedad, ca. I540, $29 \times 19 \mathrm{~cm}$. Isabella Stewart Gardner Museum, Boston.

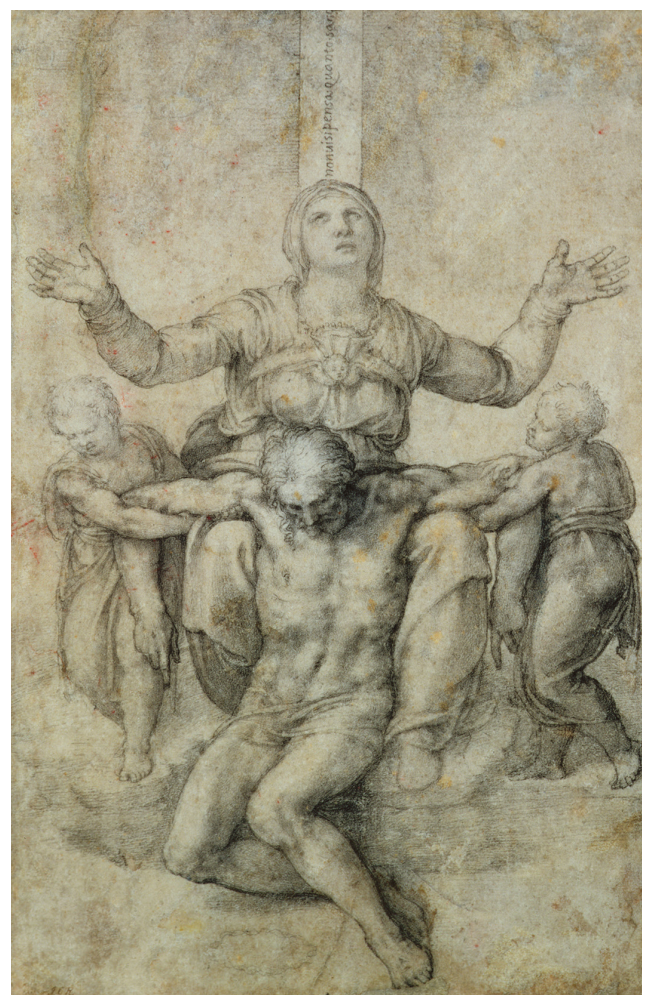

resolución intelectual..$^{30}$ A este propósito, se puede traer a colación otra vez la obra de Warburg, quien entendió la grisalla como una manera de "cristalizar las pasiones" ${ }^{3 \mathrm{I}}$ Con la grisalla, el pathos propio del arte clásico es reintroducido en el presente renacentista por medio de una operación de mediación y distanciamiento formal. D'Elia, por otro lado, explica la tensión entre forma y significado como una reflexión acerca de la naturaleza misma de la imagen sagrada,

30. Una Roman D’Elia, “Drawing Christ's Blood: Michelangelo, Vittoria Colonna, and the Aesthetics of Reform", Renaissance Quarterly 59, núm. I (2006): 90-I29.

31. Alessandra Pedersoli, "Riemersione, infezione/affezione, invasione/protagonismo, ritorno. Figure en grisaille nel Bilderatlas Mnemosyne di Aby Warburg (tavole 37, 44, 45 e 49)", Engramma, núm. IOo (20I2), en http://www.engramma.it/eOS/index.php?id_articolo=II6o; Salvatore Settis, "Aby Warburg, il demone della forma. Antropologia, storia, memoria", Engramma, núm. Ioo (20I2), en http://www.engramma.it/eOS/index.php?id_articolo=II39 
que es, por un lado, imagen de Dios y, por otro, no debe reducir a Dios a una imagen, por su carácter infinito. En otras palabras, el arte no puede convertir a Dios en un ídolo. El carácter finito en la anatomía y demás detalles realistas contrastan fuertemente con la ausencia de color, el principal signo de vitalidad en una representación. Estas características nos hablan de un círculo de mecenas y artistas que pensaba de manera profunda e independiente sobre los asuntos que preocupaban al mundo cristiano en la época de la Contrarreforma a los dos lados del Atlántico. ¿Cuál es el papel de las imágenes sacras? ¿Qué significa representar, en paredes, tablas o puestas en escena, el ocaso definitivo de la experiencia humana de Cristo? ¿Qué sigue? En Yanhuitlán, la transición y ambigüedad del estado de la imagen llega a otra novedosa solución formal en la tabla de la Piedad.

\section{La Piedad}

La filiación estilística flamenca de la Piedad subrayada arriba bien se adapta al tema piadoso y devocional de la pintura (fig. 2). Desde la época de Isabel la Católica, los pintores flamencos gozaron de una tremenda popularidad en la Península Ibérica donde imágenes como la Lamentación eran muy frecuentes, sobre todo en el ámbito privado. ${ }^{32}$ En la colección de la reina Isabel, hoy parte de la Capilla Real de Granada, hay numerosos ejemplos de escenas del Descendimiento, como en el tríptico de Dirk Bouts y en otro copia de Roger van der Weyden (fig. I2), o de la combinación de este mismo tema con el de la Piedad y el varón de los Dolores en unas obras de Hans Memling. En todos estos casos, la similitud con la Piedad de Yanhuitlán es evidente por la postura del cuerpo de Cristo, presentado de frente y erguido, cuyos brazos se extienden evocando la posición del Crucificado, misma que adoptó Miguel Ángel en el dibujo presentado anteriormente. Como es bien sabido, el maestro florentino trabajó el tema de la Piedad durante toda su carrera, mezclando prototipos clásicos, nórdicos y bizantinos. La representación frontal, de medio busto y casi bidimensional se inspira en la tipología de la Imago Pietatis de origen bizantino, iconos que en muchos casos se creía no habían sido creados por mano humana sino que eran una impresión directa del cuerpo de Cristo sobre el lienzo o

32. Véase, por ejemplo, Joaquín Yarza Lauces, Isabel la Católica. Promotora artística (León: Edilesa, 2005). 
I2. Copia de Rogier van der Weyden, la Piedad, I435-I438, 7I × 43 $\mathrm{cm}$. Capilla Real de Granada.

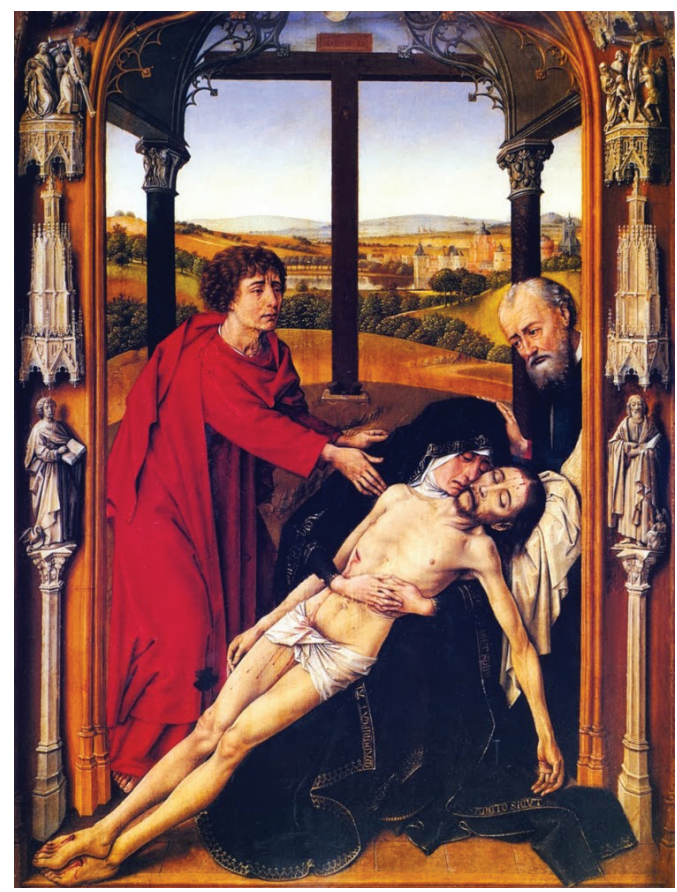

la tabla. ${ }^{33}$ La imagen icónica de la Imago Pietatis bizantina, dentro del sistema naturalista del Renacimiento, se retoma en un sentido decididamente arcaizante para subrayar la ruptura entre la naturalidad humana y la trascendencia divina. El estado natural, caído y pecador del hombre, algo que las artes liberales del ideal clásico lograron plasmar con nitidez, imposibilitan cualquier identificación total con Dios. ${ }^{34}$

33. Alexander Nagel, Michelangelo and the Reform of Art (Nueva York: Cambridge University Press, 2000), I70.

34. Otros artistas intentaron fusionar el prototipo nórdico de la Piedad (Vesperbild) con la tradición bizantina de los iconos, conjugando la experimentación artística con el reformismo religioso. Alexander Nagel, "Experiments in Art and Reform in Italy in the Early I6 ${ }^{\text {th }}$ Century", en eds. Kenneth Gouwens y Sheryl E. Reiss, The Pontificate of Clement VII. History, Politics, Culture (Burlington: Ashgate, 2005), 392-397; Claudia Cieri Via, "Sebastiano del Piombo e la Pietà di Ubeda fra narrazione e devozione", Konsthistorisk Tidskrift/Journal of Art History 8I, núm. 4 (20I2): 262-269. 
Al acercarnos nuevamente a la Piedad de Yanhuitlán, es notable que la representación frontal del cuerpo de Cristo esté rodeada de una escena extremadamente dinámica, a diferencia de todos los ejemplos citados anteriormente. El artista de la tabla, por tanto, pensó en otras soluciones formales, fuera y en contraste con la hierática Imago Pietatis. En la imagen se instaura efectivamente una tensión entre la figura estática del centro y Juan, la Virgen y los demás personajes que la rodean. No queda claro dónde se encuentran José de Arimatea y Nicodemo, los personajes que aparecen detrás de Cristo, cuya posición elevada crea un movimiento ascensional en dos niveles, mientras las dos mujeres al lado de Jesús dan solidez a la parte inferior de la composición. Se crea así una tensión entre la acción o narración del evento y la meditación sobre la figura del cuerpo de Cristo. ${ }^{35}$ Mientras la narración sitúa el acontecimiento de la muerte de Jesús en el tiempo transitorio de las cosas humanas, en la manera típica del renovado naturalismo renacentista, la representación del cuerpo como icono devuelve la imagen a su antiguo estatus simbólico, expresando el valor escatológico del sacrificio de Cristo. Por un lado, está el tiempo presente, el tiempo/espacio en el cual se desarrolla la escena y se mueve el observador; por otro, la imagen de Cristo se abstrae de la historia y adquiere un significado especial, siempre dirigido al espectador devoto. En la Piedad de Yanhuitlán, la narración histórica profana llega a un límite insuperable al toparse con el misterio de la muerte de Cristo. La conflación irresuelta no es sólo expresión de una tensión entre géneros de pintura, sino que la dinámica entre los géneros mismos induce a una reflexión sobre los límites de la creación artística respecto a la verdad de la religión.

La Piedad y el Descendimiento de Yanhuitlán postulan, por un lado, que la imagen de Cristo es necesaria para alcanzar la salvación; sin embargo, por otro, subrayan la intrínseca limitación de las mismas imágenes materiales, las cuales no pueden conducir a una salvación total en este mundo, sino que permanecen más bien como una promesa escatológica. El vaso, que contiene los santos óleos usados para preparar el cuerpo antes de su sepultura, es cargado por una mujer en la parte inferior del Descendimiento y por un hombre en la parte superior izquierda de la Piedad. En el lado derecho de la misma pintura, un hombre carga la corona de espinas y, por último, se concede mucha importancia al lienzo-sudario en el que se va a envolver el cuerpo de Cristo. Estos elementos se presentan

35. Tal es el caso también del Entierro de Miguel Ángel, hoy en la National Gallery en Londres. Nagel, Michelangelo, 7I-82. 
como reliquias, no sólo en su sentido metonímico (parte presente de un todo ausente), sino también como sinécdoque (el olor y el tacto de la corporalidad), presencia efímera, del cuerpo de Jesús. La importancia concedida al lienzo-sudario, en el cual se imprime, en grisalla, la imagen verdadera de Cristo, habla del cuerpo de Jesús, pero también de su ausencia. Se señala a la vez que se cubre el cuerpo y su presencia, únicos elementos capaces de otorgar la salvación. ${ }^{36}$

\section{Discusión y conclusión}

El análisis de las imágenes propuesto indica que en Yanhuitlán había un entendimiento profundo de las problemáticas alrededor de la imagen sacra, en sintonía con los debates europeos en la época de la Reforma y el Concilio. Aún así, el contexto de las obras, tan alejado de Europa y tan vinculado al mundo mesoamericano, nos ofrece la oportunidad ahora, así como a los frailes, espańoles y mixtecos en su época, de reflexionar acerca de la cambiante función de la imagen al transitar desde un contexto autóctono a otro en el cual la autonomía y la hegemonía tradicionales indígenas, españolas y eclesiásticas eran continuamente objeto de negociación. Las dos imágenes que nos ocupan pueden considerarse en efecto como una interfaz entre el mundo simbólico-religioso y la realidad sociopolítica de Yanhuitlán en la segunda mitad del siglo xvi que se esbozó a principios de este artículo.

El Descendimiento y la Piedad son dos capturas instantáneas de representaciones teatrales y procesiones que se han celebrado en el pueblo desde la época de la colonia hasta el día de hoy. La representación del Descendimiento, Pésame a la Virgen y Procesión del Santo Entierro siguen llevándose a cabo de una manera muy similar a la relatada por Dávila Padilla según se mencionó arriba. ${ }^{37}$ En la capilla del Calvario, en el extremo norte del poblado, se venera desde el siglo xvI una imagen de Cristo crucificado conocida hoy como Cristo de Ayuxi, el nombre de uno de los barrios del pueblo. ${ }^{38}$ En un documento fechado en

36. Powell, Depositions, 223.

37. Para una descripción, véase Mora y Molinari Soriano, Tradición e identidad; Alessia Frassani, Artistas, mecenas y feligreses en Yanhuitlán, Mixteca Alta. Siglos XVI-XXI (Ciudad de México/Bogotá: Universidad Nacional Autónoma de México-Instituto de Investigaciones Estéticas/Ediciones Uniandes, 2017), 283-296.

38. Francisco de Burgoa, Palestra historial (Ciudad de México: Talleres Gráficos de la Nación, I934), 346. 
I606 se declara que representantes de pueblos sujetos a Yanhuitlán solían participar con sus propios Cristos en cruz en las celebraciones de Semana Santa en la cabecera. ${ }^{39}$ Otro documento, fechado en 1677 , atestigua que unos residentes locales pidieron permiso para terminar una capilla en la que una imagen de Jesús Nazareno se veneraba. No solamente la imagen atraía gran devoción por los residentes de Yanhuitlán y otras áreas circundantes, sino que la capilla misma se había estado usando desde hacía años como "casa de la comunidad," más probablemente de un barrio local. ${ }^{\circ}$

Así, en I7II, en un documento se lee:

dijimos que teniendo como tiene dho nuestro barrio [Ayuxi] una milagrosa ymagen de nuestro señor crucificado que sacamos en procision la semana santa como los demas barrios de que se compone este pueblo como es publico y notorio y para su mayor culto, aseo y reverencia eleximos entre nosotros un principal de dho nuestro bario por mayordomo y en cuyo poder entregose la limosna y demas bienes de dha santa ymagen y para la selebración de la otaba de Corpus questa repartida por dias y barios $[\ldots] .^{4 r}$

Hasta los años 50 o 60 del siglo pasado, una procesión de crucifijos acompañaba durante las procesiones de Viernes Santo y Domingo de Resurrección, el Santo Entierro, la Virgen y san Juan. ${ }^{42}$ Estas cruces se encuentran hoy en la iglesia (fig. I3). Cada crucifijo llevaba un nombre propio asociado a un antiguo barrio del pueblo (Yuxayo, Tindee, Yuxacohoyo, Saayuxo, Ayuxi, Danaa, Yuyuxa, Ticoo). La importancia de los barrios en la vida política yanhuiteca a lo largo de la época colonial y en relación a otras instituciones indígenas locales, tales como el cacicazgo y la encomienda, ha sido ampliamente discutida en una publicación anterior. ${ }^{43}$ Lo que cabe señalar aquí es la relevancia de este

39. АнJT, Sección Criminal, leg. 07, exp. 39.

40. Archivo General de la Nación (en adelante AGN), Ramo Indios, leg. 25, exp. 2I4, fols. I63-I63v.

4I. AHJT, Sección Criminal, leg. 20, exp. 9. Para los Cristos en la tradición oaxaqueña colonial, véase Pablo F. Amador Marrero, "Imaginería ligera en Oaxaca. El Taller de los grandes Cristos", Boletín de Monumentos Históricos, núm. Is (2009): 45-60.

42. Ross Parmenter, Week in Yanhuitlan (Albuquerque: University of New Mexico Press, 1964), 365-366; Manuel Toussaint, Paseos coloniales, 7I.

43. Frassani, Artistas, mecenas y feligreses en Yanhuitlán, Mixteca Alta, 205-216; 257-299. 


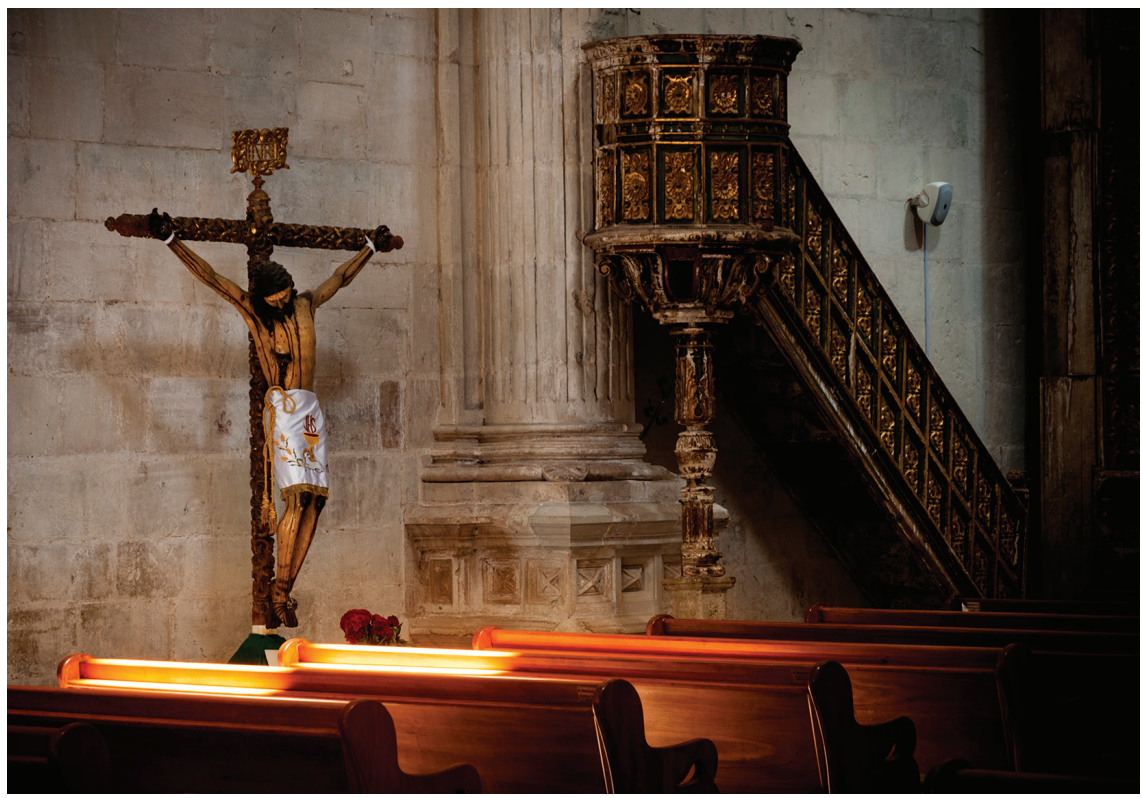

I3. Cristo de barrio, iglesia de Yanhuitlán. Foto: Javier García.

sustrato sociopolítico para la interpretación de la imagen religiosa, tal como se evidencia en los ejemplos documentales citados. El icono público y comunitario de los Cristos de barrio contrasta fuertemente con la imagen piadosa y privada del Descendimiento y la Piedad. Aun así, éstas constituyen un antecedente fundamental para entender el proceso de apropiación del culto cristológico en Yanhuitlán colonial.

La apropiación y veneración de la/s imagen/es de Cristo según patrones locales ayuda a entender la explícita referencia a los límites de la veneración de la imagen en la pintura y bajorrelieve de los objetos de análisis. La estrategia de apropiación por parte de los mixtecos de Yanhuitlán indica que la deposición de Cristo, ejecutada ritualmente cada año durante Semana Santa y representada de forma permanente en el Descendimiento y la Piedad, descalifica la imagen del poder que tuvo en su origen, cuando sirvió como instrumento de evangelización e imposición religiosa. La reducción semiótica de la imagen del dios cristiano equivale virtualmente a su desacralización y permite así una manipulación despreocupada y más afín a intereses locales. De manera astuta y sabia, el presente caso mixteco expone la queja más frecuentemente empleada por 
los frailes para justificar su presencia y censura en la vida artístico-religiosa de los pueblos indígenas: la continua amenaza de la idolatría. El cuerpo muerto de Cristo en el Santo Entierro desfilaba acompañado por numerosos Cristos en la cruz luego de su deposición pública y teatralmente conmovedora. La imagen muerta, desarticulada y depuesta resurge así en un número de signos-iconos repetidos y redundantes para indicar que su significado no está en un supuesto referente externo e impuesto (la doctrina de los frailes), sino que se construye acorde a una situación relacional específica. ${ }^{44}$ No es ya el modelo lo que da autoridad a la imagen, sino la red de referencias en la cual ésta opera: en este caso, la situación geopolítica de los barrios, anclados al paisaje ancestral de la comunidad.

Las dos imágenes del Descendimiento y la Piedad permiten entender el proceso que tuvieron que atravesar los símbolos de la religión católica impuestos tras la Conquista para poder funcionar en el contexto local. Estas representaciones de Cristo son una explícita referencia a la manipulación de la imagen y su lugar ambiguo y oscilante entre icono y signo, que abre una brecha necesaria para poder mediar entre dos mundos y culturas tan diferentes, pero convergentes, en la situación local yanhuiteca.

Los complejos matices del debate sobre la imagen sacra que se estaban dando en Europa se tradujeron en Yanhuitlán en el revuelco desde adentro de los elementos constitutivos de la imagen misma para que ésta pudiera seguir sirviendo a los intereses ideológicos locales, basados en relaciones simbólicas e ideológicas consolidadas. La deposición y representación de la imagen de Cristo en el contexto pasionario yanhuiteco demuestra que el poder religioso es un fetiche incapaz de mantener su vigencia cuando no logra una exitosa alianza con los entramados locales. is

44. Amy Knight Powell, "A Point 'Ceaselessly Pushed Back': The Origin of Early Netherlandish Painting", The Art Bulletin 88, núm. 4 (2006): 719-720.

N. B. Este ensayo es producto de una investigación financiada por el European Research Council en el marco del European Union's Seventh Framework Programme (FP/2007-2013) / ERC Grant Agreement No. 295434, "Time in Intercultural Context”. 